\title{
Correlation nitric oxide level and homeostatic model assessment insulin resistance in obese adolescent
}

\author{
Julinar*, Eka Agustia Rini, Hafni Bachtiar, Fadil Oenzil \\ From 7th APPES Biennial Scientific Meeting \\ Nusa Dua, Bali. 14-17 November 2012
}

\section{Background}

childhood obesity is a significant health problem that has reached epidemic proportions around the world. Childhood obesity associated with increased risk for several cardiovascular and metabolic syndrome, such as insulin resistance. Homeostatic model assessment insulin resistance (HOMA-IR) is a marker widely used for insulin resistance. Nitrit oxide (NO) has important role in insulin resistance.

\section{Objective}

To determine correlation between NO and HOMA-IR in obese adolescent.

\section{Method}

A cross sectional study was performed in 44 obese senior hight school students in Padang from December 2011 until March 2012. Chosen through multi stage random sampling, devidedinto 2 groups; 22 in insulin resistance and 22 in non insulin resistance. Variables measured were HOMA-IR with calculated based on fasting glucose and insulin level, serum NO levels. Data was analyzed statistically with computerization system using regression correlation test and $\mathrm{T}$-test. $\mathrm{P}<0.05$ was significant.

\section{Result}

There was significant difference in body mass index between insulin resistance and non resistance group $\left(32.53 \pm 2.57\right.$ vs $\left.30.55 \pm 3.03 \mathrm{~kg} / \mathrm{m}^{2}\right)$. Glucose level was no significant difference between insulin resistance and non resistance group $(4.93 \pm 0.79$ vs $4.66 \pm 1.02 \mathrm{mmol} / \mathrm{L})$.

Endocrinology Division, Pediatric Health Departement of Medical Faculty Andalas University, Dr.M.DjamilHospital Padang

insulin was significant difference between insulin resistance and non resistance group $(20.23 \pm 4.03$ vs $15.82 \pm 5.72 \mathrm{uIU} / \mathrm{ml}$. Nitrit oxide level was significant difference between insulin resistance and non resistance group $(70.07 \pm 24.98$ vs $55.04 \pm 19.66 \mathrm{umol} / \mathrm{L}$. There was significant correlation between NO level and HOMA IR $(\mathrm{r}=0.482 ; \mathrm{p}=0.001)$ and no significant correlation between BMI and NO levels $(r=0.135 ; \mathrm{p}=0.325)$.

\section{Conclusion}

Nitrit oxide is significantly associated with HOMA-IR in obese adolescent.

Published: 3 October 2013

doi:10.1186/1687-9856-2013-S1-P84

Cite this article as: Julinar et al:: Correlation nitric oxide level and

homeostatic model assessment insulin resistance in obese adolescent International Journal of Pediatric Endocrinology 2013 2013(Suppl 1):P84.

Submit your next manuscript to BioMed Central and take full advantage of:

- Convenient online submission

- Thorough peer review

- No space constraints or color figure charges

- Immediate publication on acceptance

- Inclusion in PubMed, CAS, Scopus and Google Scholar

- Research which is freely available for redistribution

Submit your manuscript at www.biomedcentral.com/submit
() Biomed Central 